\title{
Use of the partogram by doctors and midwives at Odi District Hospital, Gauteng, South Africa
}

\author{
OM Maphasha ${ }^{a}$, I Govendera*, DP Motloba ${ }^{b}$ and C Barua ${ }^{a}$ iD \\ ${ }^{a}$ Department of Family Medicine and Primary Health Care, Sefako Makgatho Health Sciences University, Pretoria, South Africa \\ ${ }^{\circ}$ Department of Community Dentistry, Sefako Makgatho Health Sciences University, Pretoria, South Africa \\ *Corresponding author, email: indiran.govender@gmail.com
}

Background: There is scientific evidence that using the partogram reduces maternal and foetal morbidity and mortality. The use of partograms by doctors and midwives at Odi District Hospital has been reported as inadequate by external audits. The level of knowledge of and use of partograms amongst doctors and midwives at Odi District Hospital was investigated.

Methods: A cross-sectional survey of doctors and midwives was undertaken using a self-administered questionnaire. A mixedmethods research approach was used to elicit information on the knowledge and use of the partogram.

Results: Despite 57 (83.8\%) participants having had some form of training on the partogram, only 54 (79.4\%) routinely used it. All but one participant had heard of the partogram. Reasons for not using the partogram included being unsure how to use it (13\%), partogram charts not available (8.7\%), partogram takes too long (21.7\%), being too busy (26.1\%), and a feeling that the partogram was not the doctor's responsibility (26.1\%). Overall knowledge of partograms was insufficient, resulting in inadequate use of partograms. In-service training is required to improve the skills of doctors and midwives in the correct knowledge and use of partograms.

Conclusion: Partograms are not used as required by doctors and midwives, and further training is needed.

Keywords: district hospital, doctors and midwives, in-service training, knowledge and use of partograms, partogram

\section{Introduction}

South Africa reports an unacceptably high rate of maternal deaths of 138 per 100000 live births.' Gauteng province is ranked second to KwaZulu-Natal, with maternal deaths at 138.3. ${ }^{2}$

Evidence points to a $44 \%$ decline in the global maternal mortality rate, from 385 to 216 deaths per 100000 live births between 1990 and 2015. ${ }^{1}$ This significant achievement is attributed in part to the use of the partogram to improve labour management. The Safe Motherhood Initiative concluded that use of the partogram reduced maternal and foetal morbidity and mortality, especially in under-resourced countries., ${ }^{3,5,6}$ According to Mathibe-Neke, ${ }^{3}$ 'The correct use of the partogram should become the norm in each institution conducting births.' Hence the correct use of the partogram has become part of the standard protocol for monitoring and managing labour.,

The partogram or labour graph is used to map the cervical dilatation against time and thus unsatisfactory progress of labour can be identified and managed timeously. ${ }^{5}$ The inclusion of the partogram in the labour book follows a recommendation that all facilities providing delivery services should use partograms. ${ }^{4,15}$ Thorough knowledge and consistent use of the partogram by healthcare professionals is critical in the early detection of prolonged labour and prevention of associated complications. $^{6}$

The meticulous use of the partogram has been shown to be beneficial in differentiating abnormal labour progress, and prevention of complications due to obstructed and prolonged labour. ${ }^{7,8}$ In order for the doctor to make a decision to augment labour or not, he/she must consider the estimated foetal weight and adequacy of the woman's pelvis, and there should be appropriate continuous foetal monitoring. ${ }^{8}$ Maternal complications associated with obstructed labour are uterine rupture and pressure necrosis of the bladder, which can lead to fistula formation, ${ }^{7,8}$ the most common cause being cephalopelvic disproportion, and the most appropriate intervention is Caesarean section. The foetal complications associated with obstructed labour are cerebral palsy, hypoxic ischaemic encephalopathy and eventually intrapartum-related neonatal deaths. ${ }^{9}$

The clinical value of the partogram depends on accurate observations, correct completion of the partogram and effective application of findings for effective clinical decision-making. ${ }^{10-12}$ Yet the majority of doctors either do not use the partogram or fail to complete plotting of the chart, except when checking midwives' findings without clinical confirmation. ${ }^{12}$

Doctors and midwives at Odi District Hospital in Mabopane, Gauteng, revealed poor use and inadequate knowledge and understanding of the partogram on a national audit. Effective use of the partogram by healthcare workers requires formal instruction and ongoing in-service training. ${ }^{13,15}$

The objective of this study was therefore to investigate knowledge of and use of the partogram amongst doctors and midwives at Odi District Hospital.

\section{Methodology}

\section{Study design}

A descriptive cross-sectional survey of doctors and midwives was undertaken at Odi District Hospital. This hospital has 49 maternity beds and provides maternity services and care to the 
surrounding rural areas. The staff complement includes advanced midwives, midwives, enrolled nurses, nursing assistants, fulltime medical officers and visiting specialist obstetricians. A wide range of maternity services is provided at this site, including antenatal and postnatal care and prevention of mother-to-child transmission of HIV. ${ }^{13,15}$

A self-administered questionnaire was distributed by the researcher and completed by all eligible participants. Since this study was a census, no sampling was done. Data were collected on sociodemographic variables (age, gender and experience) and the participants' level of knowledge about the partogram and how they use the partogram, from February 1, to March 31, 2015. Data were analysed using the Statistical Package for Social Sciences software (SPSS version 23.0๑, IBM Corp, Armonk, NY, USA).

\section{Data-collection instrument and scoring}

The questionnaire was based on the Guidelines for Maternity Care in South Africa ${ }^{14}$ and included three themes: (i) knowledge about the use and implications of the partogram; (ii) knowledge regarding an abnormal partogram; and (iii) knowledge about completion of certain parameters on the partogram. There was a total of 20 items (questions). Responses for questions included yes or no answers, and options rated agree, disagree or unsure. In order to produce a summation of themes and overall score for partogram use, a scoring method was devised. Each correct response was given a score of 1 and an incorrect response a 0 score, and these were converted into percentages.

For each section on knowledge the scores of the items were added and the total divided by the number of items, giving the mean score for the section. The theme and total scores were further categorised into two groups, based on levels of competence. The first group had a total score below $75 \%$ and the second group a score of $75 \%$ and above. According to the World Health Organization, ${ }^{17}$ trained and skilled healthcare workers are expected to be competent in the use of the partogram, be able to examine a pregnant woman, document findings on the partogram and interpret those findings.

Univariate descriptive data analysis summarised the variables according to measures of central tendency (mean, mode, median), measures of dispersion, range and standard deviation, as well as frequencies. Chi-square and Student's t-tests were used to test hypotheses concerning association of variables. All the inferential statistical test results were considered significant if $\alpha=0.05$ or $p<5 \%$. Data from the open-ended question were analysed using thematic content analysis.

The research was approved by the Sefako Makgatho Health Sciences Research and Ethics Committee (MREC/M/332/2014: PG). Permission to conduct the study at the site was given by the CEO of Odi District Hospital, and participants completed informed consent prior to entering the study.

\section{Results}

\section{Demographic profile of study participants}

A response rate of $97.2 \%(n=69)$ was achieved in this study. Two non-respondents included a doctor on maternity leave and another who refused to participate. The majority of the participants were doctors $(53.6 \% ; 37)$, of whom $23.2 \%$ (16) were medical officers, $18.8 \%$ (13) family medicine registrars, $8.7 \%(6)$ community service doctors and $2.9 \%$ (2) specialists.
Table 1: Demographic profile of the participants

\begin{tabular}{lcc}
\hline Variable & Frequency & $\%$ \\
\hline Professional category & 32 & \\
\hline Nurses & 37 & 46.4 \\
\hline Doctors & & 53.6 \\
\hline Sex & 27 & \\
\hline Male & 42 & 39.1 \\
\hline Female & & 60.9 \\
\hline Age (years) & 26 & \\
\hline 35 and younger & 29 & 37.7 \\
\hline Between 36 and 49 & 14 & 42.0 \\
\hline 50 and over & & 20.3 \\
\hline Experience $(n=66)$ in years & 19 & \\
\hline 5 and less & 23 & 28.8 \\
\hline Between 6 and 10 & 24 & 34.8 \\
\hline 11 and over & 69 & 36.4 \\
\hline Total & & 100 \\
\hline
\end{tabular}

The average age (SD) was 40.09 (9.89) years, with most participants $(42 \% ; n=29)$ between 36 and 49 years of age. Almost two-thirds $(63.6 \% ; n=42)$ of the participants had worked for 10 years or less (Table 1 ).

\section{Use of the partogram amongst doctors and midwives}

All participants except one $(98.6 \% ; n=68)$ had heard of the partogram, and $83.8 \%(n=57)$ had received training on the partogram - during their undergraduate training in $60.4 \%$ $(n=35)$, or during in-service rotations $(22.4 \% ; n=13)$. Over twothirds $(79.4 \% ; n=54)$ of participants routinely used the partogram. A variety of reasons were cited for not using the partogram, including being too busy $(26.1 \% ; n=6)$, the partogram taking too long $(21.7 \% ; n=5)$, and feeling that the partogram should be completed by the nurses $(26.1 \% ; n=6)$ (Table 2$)$.

\section{Knowledge of the partogram amongst doctors and midwives}

Generally participants knew about the partogram and its role in monitoring women in labour. Almost all of the participants $(89.9 \% ; n=62)$ knew when to start using a partogram. However, less than half $(47.8 \% ; n=33)$ were aware that a correct diagnosis of labour had to be made before recording the partogram. Many participants $(15.9 \% ; n=11)$ thought that use of the partogram increases the number of women having prolonged labour. A majority of participants, $(69.6 \% ; n=48)$ knew that the latent phase of labour should not be longer than 8 hours (Table 3 ).

In evaluating the participants' knowledge about assessment of women with poor progress in the active phase of labour, it was found that only $11.6 \%(n=8)$ specified that labour is prolonged if the cervix dilates at a rate of less than $1 \mathrm{~cm} /$ hour. The majority of participants $(97.1 \% ; n=67)$ were of the opinion that the rule of 4Ps (patient, powers, passage, passenger) should be used to assess and manage patients with poor progress in the active phase of labour and to exclude cephalopelivic disproportion $(85.5 \% ; n=59)$, and that intact membranes should be ruptured $(88.4 \% ; n=61)$. Sixty-three $(91.3 \%)$ agreed to exclude malpresentation as a possible cause of poor progress, and $87 \%$ ( $n=60$ ) would start oxytocin infusion if there were no contraindications. 
Table 2: Use of partogram amongst the doctors and midwives

\begin{tabular}{lcc}
\hline Questionnaire item & Frequency & $\%$ \\
\hline Have you heard of the partogram? & 68 & 98.6 \\
\hline Yes & 1 & 1.4 \\
\hline No & & \\
\hline $\begin{array}{l}\text { Have you had any formal training on the partogram? } \\
\text { ( } n=68)\end{array}$ & 57 & 83.8 \\
\hline Yes & 11 & 16.2 \\
\hline No & & \\
\hline Where did you receive training on the partogram? & 35 & 61.4 \\
\hline During training & 12 & 21.1 \\
\hline In service & 10 & 17.5 \\
\hline Both & & \\
\hline Do you routinely use the partogram? ( $n=68)$ & 54 & 79.4 \\
\hline Yes & 6 & 8.8 \\
\hline No & 8 & 11.8 \\
\hline Sometimes & & \\
\hline What prevents you from using the partogram? $(n=23)$ & 3 & 13.0 \\
\hline Not sure how to use it & 2 & 8.7 \\
\hline Partogram chart not available & 5 & 21.7 \\
\hline It takes too long & 6 & 26.1 \\
\hline I am too busy & 1 & 4.4 \\
\hline I do not find it useful & 6 & 26.1 \\
\hline It is the nurses' job to use the partogram & & 100 \\
\hline Total & & \\
\hline
\end{tabular}

Participants lacked confidence and working knowledge regarding the symbols and codes used to record events on a partogram. This was found when the participants were asked to draw the symbols and codes for foetal heart rate, cervical dilatation, moulding and type of liquor partogram. As many as $76.8 \%(n=53)$ did not know how to plot the foetal heart rate on the partogram, and $97.1 \%(n=67)$ could not plot moulding of skull bones.

\section{Comparison of general knowledge of the partogram and demographic characteristics}

Based on the results shown in Table 4, the general knowledge of the partogram seems to be similar irrespective of profession $(p=0.83)$, gender $(p=0.41)$, age group $(p=0.59)$, and clinical experience $(p=0.90)$. Despite lack of statistical significance $(p=0.067)$, more nurses than doctors had better skills and knowledge of the partogram. Clinical application of the partogram improves with years of experience in the maternity unit. Participants with clinical experience of over six years were significantly more knowledgeable in the application of the partogram than those with less experience $(p=0.026)$. Association of knowledge of what needs to be completed on the partogram and demographic variables was insignificant for age, gender, profession and years of experience (Table 4). Similar findings were reported on overall knowledge of the partogram and demographic parameters (Table 5).

\section{General comments from participants regarding the use of the partogram}

In this section participants were asked if they had any other comments regarding the use of the partogram. Half of all the participants $(35 ; 50.2 \%)$ responded, and four themes emerged:
Table 3: Knowledge of the partogram

\begin{tabular}{|c|c|c|}
\hline $\begin{array}{l}\text { Questionnaire items (1-7): General knowledge of } \\
\text { the partogram }\end{array}$ & Agree & Disagree \\
\hline $\begin{array}{l}\text { A partogram is a universal tool for monitoring } \\
\text { labour }\end{array}$ & $69(100)$ & 0 \\
\hline Start using partogram once the woman is in labour & $62(89.9)$ & $7(10.1)$ \\
\hline $\begin{array}{l}\text { A correct diagnosis of labour has to be made after } \\
\text { entering on the partogram }\end{array}$ & $33(47.8)$ & $36(52.2)$ \\
\hline $\begin{array}{l}\text { Use of the partogram increases the number of } \\
\text { women undergoing prolonged labour }\end{array}$ & $11(15.9)$ & $58(84.1)$ \\
\hline $\begin{array}{l}\text { Use of the partogram in monitoring labour helps to } \\
\text { identify abnormal progress }\end{array}$ & $68(98.6)$ & $1(1.4)$ \\
\hline Latent phase should not be longer than 8 hours & $48(69.6)$ & $21(30.4)$ \\
\hline $\begin{array}{l}\text { If the skull bones overlap and cannot be separated } \\
\text { it is not a sign of obstructed labour }\end{array}$ & $11(15.9)$ & $58(84.1)$ \\
\hline $\begin{array}{l}\text { Questionnaire items (8-13): Management of poor } \\
\text { progress }\end{array}$ & Agree & Disagree \\
\hline $\begin{array}{l}\text { Labour is prolonged if the cervix dilates at the rate } \\
\text { of more than } 1 \mathrm{~cm} / \text { hour (does not cross the alert } \\
\text { line) }\end{array}$ & $8(11.6)$ & $61(88.4)$ \\
\hline $\begin{array}{l}\text { Use the rule of } 4 \text { Ps in the assessment (patient, } \\
\text { powers, passage, passenger) }\end{array}$ & $67(97.1)$ & $2(2.9)$ \\
\hline Exclude cephalopelvic disproportion (CPD) & $59(85.5)$ & $10(14.4)$ \\
\hline Do not rupture the membrane if it is still intact & $8(11.6)$ & $61(88.4)$ \\
\hline $\begin{array}{l}\text { Exclude malpresentation, e.g. breech, brow } \\
\text { presentation }\end{array}$ & $63(91.3)$ & $6(8.7)$ \\
\hline $\begin{array}{l}\text { If there are contraindications start oxytocin } \\
\text { infusion }\end{array}$ & $9(13.0)$ & $60(87.0)$ \\
\hline $\begin{array}{l}\text { Questionnaire items (14-20): What needs to be } \\
\text { completed on the partogram }\end{array}$ & Correct & Incorrect \\
\hline Foetal heart rate (FHR) & $16(23.2)$ & $53(76.8)$ \\
\hline Meconium-stained liquor (MSL) & $9(13.0)$ & $60(87.0)$ \\
\hline Intact membrane & $49(71.0)$ & $20(29.0)$ \\
\hline Clear liquor & $45(65.2)$ & $24(34.8)$ \\
\hline Moulding skull bones overlap but can be separated & $2(2.9)$ & $67(97.1)$ \\
\hline Descent of the presenting part & $36(52.2)$ & $33(47.8)$ \\
\hline Cervical dilation & $43(62.3)$ & $26(37.7)$ \\
\hline
\end{tabular}

the partogram is poorly used; in-service training is needed; doctors do not plot the partogram; and spoiled partograms received from local clinics (Table 6).

\section{Discussion}

The study population is mostly less than 49 years of age, and thus we assume their clinical experience of less than 10 years $(63.6 \%)$ is still developing, similar to reports in Ethiopia and Ghana. ${ }^{15,16}$ This indicates that this cohort is young and therefore has an adequate opportunity to improve on their knowledge and application of the partogram within maternal services. The high rate of females in our study reflects a global gender bias that pervades distribution of the workforce in maternity units. ${ }^{6,17}$

This study revealed that almost all of the participants were familiar with the partogram being a universal tool for monitoring labour, similar to the findings in a study in Ghana. ${ }^{16}$ The majority (89.9\%) stated that plotting the partogram should start when a woman is in labour, compared with $40.0 \%$ in Ghana. ${ }^{16}$ Even though the participants had good knowledge about what the partogram is and its importance in the management of prolonged and obstructed labour, they did not know the symbols 
Table 4: Association of knowledge of partogram and demographic variables

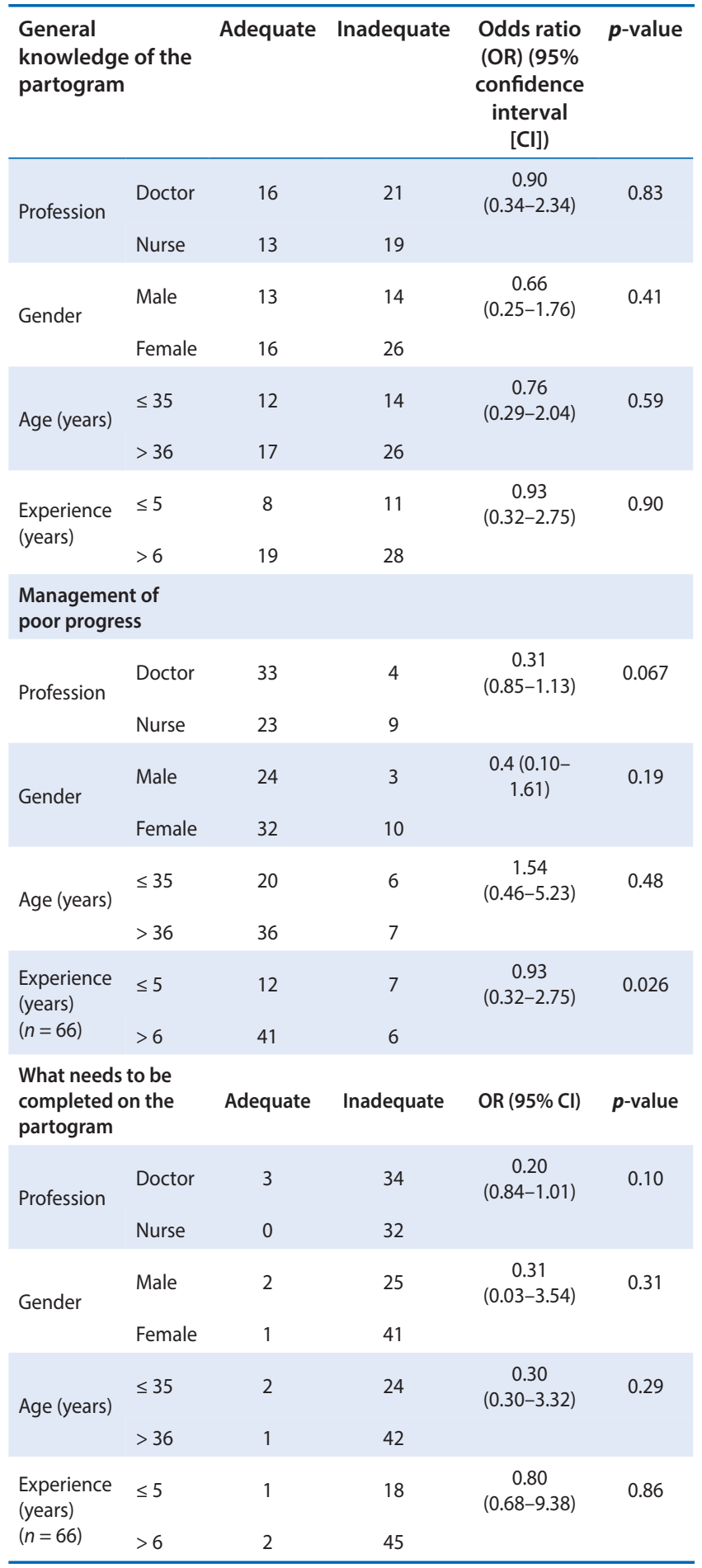

used when plotting on the partogram (e.g. FHR, MSL and moulding). This will have a negative impact on their ability to plot and interpret abnormal findings.

We attribute this poor level of knowledge to inadequate exposure, insufficient and infrequent in-service training of personnel, and lack of support and guidance. This situation has previously been cited as contributing to non-use of partograms. ${ }^{18}$ The plotting of the partogram may be difficult and challenging for the untrained healthcare professional. Cumulatively, challenges with plotting the partogram lead to doctors and midwives being resistant to this task.
Table 5: Association of overall (summative) knowledge of partogram and demographic variables

\begin{tabular}{|c|c|c|c|c|c|}
\hline \multirow[t]{2}{*}{ Variable } & & \multicolumn{2}{|c|}{$\begin{array}{c}\text { Overall level of } \\
\text { knowledge of the } \\
\text { partogram }\end{array}$} & \multirow[t]{2}{*}{$\begin{array}{c}\text { OR }(95 \% \\
\text { CI) }\end{array}$} & \multirow[t]{2}{*}{$p$-value } \\
\hline & & Adequate & Inadequate & & \\
\hline \multirow[t]{2}{*}{ Profession } & Doctor & 7 & 30 & $\begin{array}{c}0.44 \\
(0.10-1.88)\end{array}$ & 0.26 \\
\hline & Nurse & 3 & 29 & & \\
\hline \multirow[t]{2}{*}{ Gender } & Male & 5 & 22 & $\begin{array}{c}0.60 \\
(0.16-2.29)\end{array}$ & 0.45 \\
\hline & Female & 5 & 37 & & \\
\hline \multirow[t]{2}{*}{ Age (years) } & $\leq 35$ & 3 & 23 & $\begin{array}{c}1.47 \\
(0.35-6.36)\end{array}$ & 0.59 \\
\hline & $>36$ & 7 & 36 & & \\
\hline \multirow{2}{*}{$\begin{array}{l}\text { Experience } \\
\text { (years) }\end{array}$} & $\leq 5$ & 1 & 18 & $\begin{array}{c}3.69 \\
(0.43-31.78)\end{array}$ & 0.21 \\
\hline & $>6$ & 8 & 39 & & \\
\hline
\end{tabular}

Table 6: Themes regarding partograms

\begin{tabular}{|c|c|}
\hline Theme & Quotations from participants \\
\hline 1. The partogram is poorly used & $\begin{array}{l}\text { 'Some of the professionals cannot } \\
\text { use it properly; it helps to diagnose } \\
\text { and to prevent prolonged labour' } \\
\text { (midwife, } 58 \text { years) }\end{array}$ \\
\hline 2. In-service training is required & $\begin{array}{l}\text { 'Some sisters and doctors are still not } \\
\text { competent in using the partogram. } \\
\text { Organising formal training for them } \\
\text { like ESMOE will be beneficial' (doctor, } \\
40 \text { years) }\end{array}$ \\
\hline 3. Doctors don't plot the partogram & $\begin{array}{l}\text { 'Doctors don't plot the partogram, } \\
\text { they think it's a nurse's duty to plot } \\
\text { the partogram' (nurse, } 30 \text { years) }\end{array}$ \\
\hline $\begin{array}{l}\text { 4. Spoiled partograms from the local } \\
\text { clinics }\end{array}$ & $\begin{array}{l}\text { 'Sometimes it is difficult to use it } \\
\text { because when the patient arrives } \\
\text { from the local clinic the partogram } \\
\text { is already incorrectly filled' (doctor, } \\
31 \text { years) }\end{array}$ \\
\hline
\end{tabular}

A majority of the participants (79.4\%) routinely use the partogram, which was higher than in Ethiopia $^{19}$ (40.2\%) and Nigeria $^{20,21}$ (5 to $\left.33 \%\right)$. Human resources shortages pose a serious threat to the provision of comprehensive health services, especially in low-resource settings. Maternity wards are often understaffed, and personnel may not have adequate experience and time to complete the partogram. In our setting participants were unable to complete the partogram largely because they do not have time, and doctors considered it the nurses'responsibility to fill in in the partogram. These reasons pertaining to understaffing and its effects are universal justifications given in particular by doctors regarding their failure to use partograms. ${ }^{18,22}$

Over 25 years ago the World Health Organization declared the partogram to be an essential tool for monitoring and management of labour. ${ }^{3}$ Despite established evidence of safe and successful labour with the use of the partogram, this tool remains inconsistently and incorrectly applied and used. ${ }^{18,19}$ Most undergraduate training includes the use of the partogram, yet students tend to be less involved. ${ }^{3}$ We suggest radical curriculum changes, where students develop and maintain their own partogram records, and monitor and suggest appropriate interventions under supervision. Once qualified, graduates need to undertake regular practical refresher courses on the use of partograms. 
Facility-wide audits are critical, because use of the partogram should be integrated into the ethos of the institution as a mandate by the South African Department of Health, and not be relegated to individual preference. It is with this understanding that the leadership of the institution is likely to provide the necessary infrastructure and resources needed to establish the use of the partogram as a routine and necessary practice. Monitoring and evaluation of the partogram in institutions is critical for assessment of performance and reinforcement of learning and good performance.

\section{Limitations of the study}

The small sample size predisposes our findings to random error; however, the methodological rigour incorporated in this study minimises threats to validity. Our study was a census, which provides a complete picture of the use of partograms at Odi District Hospital. We found similarity with larger studies, which most likely makes our findings generalisable to similar settings.

\section{Conclusion}

Despite having inadequate knowledge about the partogram, the majority of doctors and midwives continue to use this tool regularly. It is encouraging that there is willingness and understanding that the partogram is essential and should be used once the woman is in labour. Management should provide leadership and adequate support to staff in order to improve knowledge and application of the partogram. Regular audits should be scheduled and implemented to increase uptake and proper implementation of the partogram at Odi District Hospital to improve the quality of intrapartum care.

Funding - This study was funded by the Discovery Foundation.

\section{ORCID}

\section{Barua (D) http://orcid.org/0000-0003-1742-0207}

\section{References}

1. World Health Organization, UNICEF, UNFPA. The World Bank, and the United Nations Population Division. Trends in maternal mortality: 1990 to 2015. Geneva: World Health Organization; 2015 [cited 2015 Sep 15]. Available from: www.worldbank.org.

2. Saving Mothers 2011-2013: Sixth report on the Confidential Enquiry into Maternal deaths in South Africa. Short report. Compiled by the National Committee for Confidential Enquiry into Maternal Deaths [cited 2015 Aug 24]. Available from: www.kznhealth.gov.za.

3. Mathibe-Neke JM. Facilitation of midwifery students regarding utilization of a partograph. Afr J Nurs Midwif. 2009;11(1):34-47.

4. Republic of South Africa. Strategic Plan for Maternal, Newborn, Child and Women's Health (MNCWH) and Nutrition in South Africa 20122016 [cited 2015 Nov 15]. Available from: www.health.gov.za.

5. USAID \& PATH. Intrapartum related events. HealthTech USAID 2012 [cited 2015 Nov 15]. p. 48. Available from: http://sites.path. org/technologysolutions/files/2012/04/HealthTech_IntrapartumRelated-Events_Rapid-Landscape_UPDATED-March-15-2012-c.pdf.

6. Yisma E, Dessalegn B, Astatkie A, et al. Knowledge and utilization of partograph among obstetric care givers in public health institutions of Addis Ababa, Ethiopia. Ethiopia. BMC Pregnancy Childbirth. 2013 [cited 2014 Feb 10];13:22. Available from: www.biomedcentral. com/1471-2393/13/17. http://dx.doi.org/10.1186/1471-2393-13-17
7. Mathai M. The partograph for the prevention of obstructed labor. Clin Obstet Gynecol. 2009;52(2):256-69. http://dx.doi.org/10.1097/ GRF.0b013e3181a4f163

8. Masika MA, Katongole PS, Govule P. Improving partograph documentation and use by health workers of Bwera Hospital: a process improvement research. Int J Nurs Health Sci. 2015;2(4):37-45.

9. Lawn JE, Lee AC, Kinney M, et al. Two million intrapartum-related stillbirths and neonatal deaths: Where, why, and what can be done? Int J Gynaecol Obstet. 2009 [cited 2016 Dec 7];107(1):S5-S19. Available from: www.newbornwhocc.org. http://dx.doi.org/10.1016/j. ijgo.2009.07.016

10. Okechukwu E, Adesegun A, Niyi O, et al. Impact of training on the use of partograph on maternal perinatal outcome in peripheral health centers. J Turkish-German Gynaecol Assoc. 2007;8(2):148-52.

11. Farrell E, Pattinson B. Intrapartum care in South Africa; review and guidelines. Parowvallei: MRC; 2005.

12. Dye TD, Alderdice F, Roberge $E$, et al. Attitudes toward clinical guidelines among obstetricians in Northern Ireland. Biomed J Obstet Gynaecol. 2000;107(1):101-7. http://dx.doi.org/10.1111/ bjo.2000.107.issue-1

13. Department of Health. Guidelines for maternity care in South Africa: a manual for clinics, community health centers and district hospitals. 4th ed. 2015 [cited 2015 Aug 24]. Available from: www.mchsa.org.

14. Gauteng Provincial Government Health Annual Report 2012/2013. Finance Management Act Rule 9.4(1) of the Gauteng Legislature Standing Rules. 2009 Aug [cited 2015 Nov 15]. Available from: http://www.health.gpg.gov.za/dohDocuments/Annual\%20Reports/ Annual\%20report\%202013\%20Gauteng\%20Department\%20of\%20 Health.pdf.

15. Markos D, Bogale D. Documentation status of the modified World Health Organization partograph in public health institutions of Bale zone, Ethiopia. Reprod Health. 2015 [cited 2016 Feb 20];12:4373. Available from: http://www.ncbi.nlm.nih.gov/pubmed/26336094. http://dx.doi.org/10.1186/s12978-015-0074-z

16. Konlan KD, Kombat JM, Wuffele MG, et al. Knowledge and attitudes of midwives on the use of the partogram: a study among midwives in the Tamale Metropolis. Maternal Health Neonatol Perinatol. 2016;2:1399. http://dx.doi.org/10.1186/s40748-016-0030-0

17. Agan TU, Akpan U, Okokon IB, et al. Assessment of the knowledge and utilization of the partograph among non-physician obstetric care givers in the University of Calabar Teaching Hospital, Calabar, Nigeria. Brit J Med Med Res. 2014 [cited 2015 Nov 15];4(36):5741-55. Available from: www.sciencedomain.org. http://dx.doi.org/10.9734/ BJMMR

18. Ogwang S, Karyabakabo Z. Assessment of partogram use during labour in Rujumbura Health Sub District, Rukungiri district, Uganda. Afr Health Sci. 2009;9(S1):27-34.

19. Wakgari N, Amano A, Berta M, et al. Partograph utilization and associated factors among obstetric care providers in North Shoa Zone, Central Ethiopia: a cross sectional study. Afr Health Sci. 2015;15(2):552-9. http://dx.doi.org/10.4314/ahs.v15i2.30

20. Fawole AO, Hunyinbo KI, Adekanie DA. Knowledge and utilization of the partogram among obstetric care givers in South West Nigeria. Afr J Reprod Health. 2008;12(1):22-9.

21. Umezulike AC, Onah $\mathrm{HE}$, Okaro JM. Use of the partograph among medical personnel in Enugu, Nigeria. Int J Gynaecol Obstet. 1999;65(2):203-5. http://dx.doi.org/10.1016/S0020-7292(98)00168-4

22. Lavender T, Hart A, Smyth RMD. Effect of partogram use on outcomes for women in spontaneous labour at term. Cochrane Database Syst Rev. 2011;8:CD005461. doi: 10.1002/14651858.CD005461.pub3.

Received: 26-09-2016 Accepted: 26-12-2016 